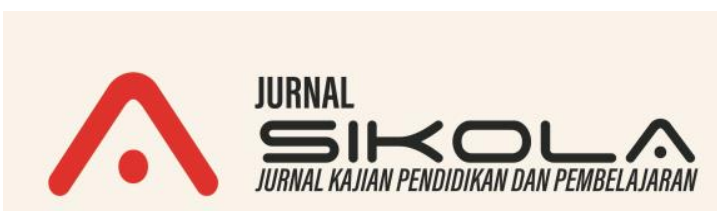

Jurnal Sikola: Jurnal Kajian Pendidikan dan Pembelajaran

VOL. 1 NO. 1 SEPTEMBER 2019

http://sikola.ppj.unp.ac.id

Email: sikola@ppj.unp.ac.id

ISSN: $\underline{2686-3413}$ (Print) 2715-1735 (Online)

DOI: https://doi.org/10.24036/sikola.v1i1.1

\title{
Pengembangan Tes Diagnostik Pilihan Objektif Tiga Tingkat Guna Mendeteksi Miskonsepsi Ciri-Ciri Sosiologi
}

\author{
Mardiani Mardiani1, Ike Sylvia ${ }^{2}$ \\ 1,2Universitas Negeri Padang

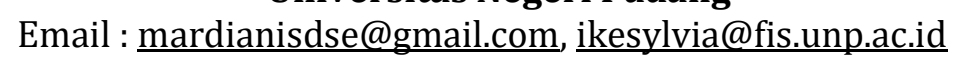

\begin{abstract}
Abstrak
Penelitian ini dilatarbelakangi dari banyaknya nilai UTS siswa yang masih berada di bawah KKM yaitu 70 terlebih pada soal-soal ciri-ciri sosiologi. Pengembangan tes diagnostik pilihan ganda tiga tingkat ini bertujuan untuk megidentifikasi miskonsepsi yang dialami oleh siswa dengan jumlah soal 20 butir. Hal ini dianalisis dengan teori tes modern/ item response theory, artinya respon subjek terhadap suatu item menunjukkan kemampuan kognitifnya. Metode yang digunakan dalam penelitian ini berupa metode pengembangan Research and Development. Model pengembangan yang digunakan adalah model yang dikemukakan oleh Tessmer (formatif evaluation). Teknik pengumpulan datanya berupa tes dan angket. Dari angket respon (efektivitas) siswa, diketahui bahwa tes diagnostik pilihan ganda tiga tingkat efektif untuk digunakan, dan dari data tes soal diketahui tingkat pemahaman siswa, persentase mengerti konsep 44,9\%, dan miskonsepsi 45,25\% serta tidak mengerti konsep 11,6\%. CVI dari soal yang dikembangkan menunjukkan hasil 0,90 dengan kategori sangat sesuai, dan reliabilitasnya 0,457 dengan kategori cukup.

Kata kunci : Ciri-ciri sosiologi, Miskonsepsi, Tes diagnostik
\end{abstract}

\section{Abstract}

This research is motivated by the number of UTS scores of students who are still below the KKM, namely 70, especially on the questions of sociological characteristics. The development of this three-tier multiple choice diagnostic test aims to identify misconceptions experienced by students with a number of questions of 20 items. This is analyzed by the theory of modern / item response theory tests, meaning that the subject's response to an item shows his cognitive abilities. The method used in this study is a method of developing Research and Development. The development model used is the model proposed by Tessmer (formative evaluation). The data collection technique is in the form of tests and questionnaires. From the response questionnaire (effectiveness) of students, it is known that the multiple-level multiple choice diagnostic test is effective to use, and from the test test data it is known the level of understanding of students, the percentage of understanding the concept is $44.9 \%$, and misconception is $45.25 \%$ and does not understand the concept of $11.6 \%$. CVI from the questions developed shows results of 0.90 with a very appropriate category, and the reliability is 0.457 with sufficient categories.

Keywords: Sociological features, Misconceptions, Diagnostic tests

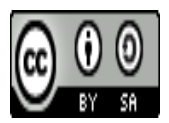

Received: August 5, 2019 Revised: August 8, 2019 Available Online: September 30, 2019

Jurnal Sikola: Jurnal Kajian Pendidikan dan Pembelajaran Vol. 1, No. 1, Th. 2019

ISSN. 2715-1735

Copyright@2019, by Author 


\section{Pendahuluan}

Pendidikan merupakan suatu upaya dalam memperoleh pembelajaran bagi siswa untuk mendorong memajukan kemampuan yang dimilikinya dari berbagai aspek (Fernandes, Putra, \& Muspita, 2013). Dalam pendidikan terdapat suatu standar proses pendidikan. Standar proses pendidikan (Sanjaya, 2008) adalah standar nasional pendidikan yang berkaitan dengan pelaksanaan pembelajaran pada satu satuan pendidikan untuk mencapai standar kompetensi lulusan. Salah satu standar yang utama dalam melihat kemampuan siswa adalah standar evaluasi (Tes et al., 2013). Yang dimaksud dengan evaluasi ialah suatu cara yang digunakan untuk menilai kesuksesan dalam pembelajaran serta untuk mengambil tindaklanjut dari proses pembelajaran tersebut (Sdn, Tujuh, \& Kecamatan, n.d.). Dengan kata lain, evaluasi juga berfungsi untuk melihat respon siswa terhadap stimulus yang telah diberikan oleh guru (Pembimbing et al., n.d.). Dapat disimpulkan bahwa, evaluasi atau penilaian pada hakikatnya merupakan upaya guru dalam memudahkan siswa mencapai apa yang seharusnya dicapainya (Pendidikan et al., 2016).

Konsep ialah istilah yang dipakai untuk mempermudah atau menyederhanakan sesuatu (Nofiana et al., 2013). Siswa sangat dituntut untuk dapat memahami berbagai konsep, karena antara konsep satu dengan konsep lainnya saling keterkaitan (Fisika, Kelas, Sma, \& Malang, 2013). Sosiologi kaya akan konsep-konsep. Karena kaya akan konsep, tidak sedikit siswa yang mengalami kesulitan dalam membedakan dua konsep yang dianggap hampir sama, meskipun pada kenyataannya terdapat perbedaan antar kedua konsep tersebut. Kesulitan dalam membedakan konsep merupakan gejala awal siswa mengalami miskonsepsi atau tidak mengerti terhadap konsep yang diberikan.

Berikut gambaran dari kesalahan konsep (miskonsepsi) siswa kelas X IPS SMA N 3 Padang Panjang saat menjawab soal uts sub materi ciri-ciri sosiologi:

\section{Tabel 1. Soal Ciri-Ciri Sosiologi}

\begin{tabular}{|c|c|c|c|c|c|c|c|}
\hline Kelas & Soal & $\begin{array}{c}\text { Jumlah } \\
\text { Siswa }\end{array}$ & A & B $^{*}$ & C & D & $\mathbf{E}$ \\
\hline 10.IPS 1 & \multirow{5}{*}{ 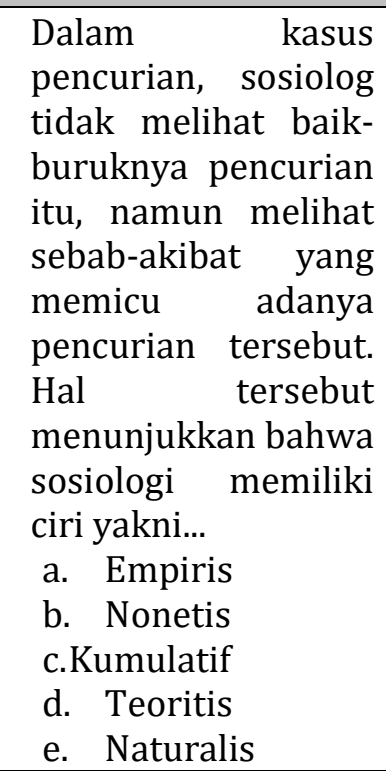 } & 34 & 9 & 7 & 2 & 9 & 7 \\
\hline 10.IPS 2 & & 33 & 10 & 13 & 0 & 7 & 3 \\
\hline 10.IPS 3 & & 34 & 11 & 10 & 6 & 5 & 2 \\
\hline 10.IPS 4 & & 33 & 7 & 12 & 4 & 7 & 3 \\
\hline 10.IPS 5 & & 32 & 10 & 10 & 7 & 5 & 0 \\
\hline Total & & 166 & 47 & 52 & 19 & 33 & 15 \\
\hline Persentase & & & $28 \%$ & $31 \%$ & $12 \%$ & $20 \%$ & $9 \%$ \\
\hline
\end{tabular}

Jurnal Sikola: Jurnal Kajian Pendidikan dan Pembelajaran Vol. 1, No. 1, Th. 2019 
Tabel 2. Soal Ciri-Ciri Sosiologi Guna Mendeteksi Miskonsepsi Ciri-Ciri Sosiologi

\begin{tabular}{|c|c|c|c|c|c|c|c|}
\hline Kelas & Soal & $\begin{array}{c}\text { Jumlah } \\
\text { Siswa }\end{array}$ & $A^{*}$ & B & C & D & $\mathbf{E}$ \\
\hline 10.IPS 1 & \multirow{5}{*}{$\begin{array}{l}\text { Sosiologi didasarkan } \\
\text { pada hasil observasi, } \\
\text { tidak spekulatif, dan } \\
\text { menggunakan akal } \\
\text { sehat. Hal ini } \\
\text { menunjukkan bahwa } \\
\text { sosiologi bersifat .... } \\
\text { a.Empiris } \\
\text { b. Teoritis } \\
\text { c.Kumulatif } \\
\text { d. Nonetis } \\
\text { e.Praktis }\end{array}$} & 34 & 22 & 0 & 5 & 5 & 2 \\
\hline 10.IPS 2 & & 33 & 16 & 2 & 7 & 8 & 0 \\
\hline 10.IPS 3 & & 34 & 17 & 2 & 1 & 8 & 6 \\
\hline 10.IPS 4 & & 33 & 14 & 3 & 4 & 9 & 3 \\
\hline 10.IPS 5 & & 32 & 23 & 1 & 4 & 3 & 1 \\
\hline Total & & 166 & 92 & 8 & 21 & 33 & 12 \\
\hline Persentase & & & $55 \%$ & $5 \%$ & $13 \%$ & $20 \%$ & $7 \%$ \\
\hline
\end{tabular}

Tabel 3. Soal Ciri-Ciri Sosiologi

\begin{tabular}{|c|c|c|c|c|c|c|c|}
\hline Kelas & Soal & $\begin{array}{c}\text { Jumlah } \\
\text { Siswa }\end{array}$ & $A^{*}$ & B & C & D & $\mathbf{E}$ \\
\hline 10.IPS 1 & 3. Perhatikan & 34 & 7 & 8 & 7 & 10 & 2 \\
\hline 10.IPS 2 & $\begin{array}{l}\text { pernyataan berikut } \\
\text { ini. }\end{array}$ & 33 & 6 & 13 & 1 & 11 & 2 \\
\hline 10.IPS 3 & 1). Sosiologi menganalisis & 34 & 9 & 8 & 6 & 6 & 5 \\
\hline 10.IPS 4 & $\begin{array}{l}\text { fakta-fakta di } \\
\text { lapangan }\end{array}$ & 33 & 5 & 11 & 3 & 12 & 2 \\
\hline 10.IPS 5 & $\begin{array}{l}\text { 2). Sosiologi berusaha } \\
\text { menyusun abstraksi } \\
\text { dari hasil-hasil } \\
\text { observasi } \\
\text { 3). Teori-teori sosiologi } \\
\text { dibentuk berdasarkan } \\
\text { teori-teori yang sudah } \\
\text { ada } \\
\text { 4). Sosiologi menilai baik } \\
\text { buruknya fakta di } \\
\text { lapangan sebagai } \\
\text { dasar penyususnan } \\
\text { laporan } \\
\text { 5). Sosiologi melakukan } \\
\text { kajian tentang hasil } \\
\text { observasi yang } \\
\text { spekulatif } \\
\text { Ciri sosiologi sebagai } \\
\text { ilmu pengetahuan } \\
\text { ditunjukkan nomor.... } \\
\text { a. (1), (2), dan (3) }\end{array}$ & 32 & 7 & 11 & 6 & 6 & 2 \\
\hline
\end{tabular}

Jurnal Sikola: Jurnal Kajian Pendidikan dan Pembelajaran Vol. 1, No. 1, Th. 2019 
b. (1), (4), dan (5)

c. (2), (3), dan (4)

d. (2), (3), dan (5)

e. (3), (4), dan (5)

\begin{tabular}{ccccccc}
\hline Total & 166 & $\mathbf{3 4}$ & 51 & 23 & 45 & 13 \\
\hline Persentase & & $\mathbf{2 0} \%$ & $31 \%$ & $14 \%$ & $27 \%$ & $8 \%$ \\
\hline
\end{tabular}

Gambaran tabel 1-3 menunjukkan bahwa seorang guru perlu mendeteksi miskonsepsi yang dialami oleh siswa guna untuk mengambil tindak lanjut dari permasalahan tersebut, agar miskonsepsi bisa diminimalisir. Selama ini, guru hanya melakukan penilaian terhadap siswa lewat hasil ulangan harian, sehingga susah terdeteksi miskonsepsi yang dialami siswa (Manfaatnya \& Mengukur, 2009).

Terdapat banyak alat untuk mengungkap miskonsepsi yang dihadapi oleh siswa, disini peneliti berupaya dalam mengungkap miskonsepsi siswa menggunakan tes diagnostik pilihan objektif tiga tingkat (Zulfikar, Samsudin, \& Saepuzaman, 2017). Tes diagnostik adalah tes yang diberikan kepada siswa untuk mendeteksi titik lemah siswa dalam menghadapi kesulitan belajar (Belajar \& Di, n.d.). Semua siswa tentu berkeinginan untuk mendapat peluang nilai tinggi (Jurusan \& Penyuluhan, n.d.). Setelah dilakukan tes diagnostik ini, guru dapat melakukan remedi bagi siswa yang tidak tuntas, agar mencapai ketuntasan (Ismara \& Tanumihardja, 2015). Tes diagnostik ini terdiri dari tiga tingkatan. Pada tingkat pertama, siswa diminta untuk menjawab soal, pada tingkat kedua, siswa diminta untuk memilih alasan dalam menjawab soal tingkat pertama, dan pada tingkat terakhir, siswa diminta untuk menentukan tingkat keyakinannya dalam menjawab soal serta memberikan alasan yang ia anggap sudah tepat. Melalui jawaban pada tingkat 1-3, guru dapat mendeteksi miskonsepsi yang terjadi (Suwarto, 2013).

Setelah dilakukan observasi dan wawancara dengan guru sosiologi SMAN 3 Padang Panjang, didapatkan penjelasan bahwa selama ini guru sosiologi hanya memberi tes untuk melihat hasil belajar siswa tanpa pernah melihat tingkat miskonsepsi yang dialami oleh siswanya. Tes diagnostik pilihan objektif ini dapat membantu guru untuk melihat siswa yang mengerti akan konsep, miskonsepsi, bahkan untuk mengetahui siswa yang sama sekali tidak mengerti akan konsep yang teah dipaparkan oleh guru. Sosiologi sebagai ilmu pengetahuan yang berdiri sendiri karena telah memenuhi segenap unsur-unsur ilmu pengetahuan, yang ciriciri utamanya adalah sebagai berikut (Soekanto, 2017) : a. Sosiologi bersifat empiris (fakta ), b. Sosiologi bersifat teoritis ( menyusun abstraksi dari hasil observasi), c. Sosiologi bersifat kumulatif (memperbaiki, memperluas, memperhalus teori lama), dan d. Sosiologi bersifat nonetis( tidak mempersoalkan baik buruknya fakta). Ketika siswa mengalami kesulitan dalam belajar, dipastikan nilai siswa tersebut berada di bawah standar yang telah ditentukan (Di \& Serang, 2013). Pada sub materi ciri-ciri sosiologi tersebut, kebanyakan siswa kelas X SMA N 3 Padang Panjang dalam menjawab soal masih terkendala, terbukti dari nilai UTS siswa masih banyak di bawah standar yaitu 70 terutama pada saat menjawab soal dalam bentuk analisa.

Penelitian ini bertujuan untuk mengidentifikasi miskonsepsi siswa kelas X SMAN 3 Padang Panjang pada sub materi ciri-ciri sosiologi sekaligus melihat interpretasi dari validitas serta reliabilitas tes diagnostik pilihan objektif tiga tingkat yang diujikan. Penelitian ini dianalisis menggunakan teori tes modern/ item response theory, artinya respon subjek terhadap suatu item menunjukkan kemampuan kognitifnya.

Jurnal Sikola: Jurnal Kajian Pendidikan dan Pembelajaran Vol. 1, No. 1, Th. 2019

ISSN. 2715-1735 


\section{Metode Peneitian}

Jenis penelitian yang digunakan dalam penelitian ini adalah penelitian pengembangan (Research and Development). Metode penelitian dan pengembangan dapat diartikan sebagai cara ilmiah untuk meneliti, merancang, memproduksi, dan menguji validitas produk yang telah dihasilkan. Berdasarkan pengertian tersebut, kegiatan penelitian dan pengembangan dapat disingkat menjadi 4P (penelitian, perancangan, produksi, dan pengujian) (Sugiyono, 2017).

Penelitian ini dilaksanakan di SMA N 3 Padang Panjang pada semester 1, tahun ajaran 2019/2020 tepatnya pada bulan Juli 2019 untuk uji skala luas, sedangkan uji coba one-to-one dan uji coba small grup diadakan pada bulan Juni 2018 pada ajaran 2018/2019. Objek penelitian dalam penelitian ini adalah alat ukur diagnostik yang dikembangkan dalam bentuk soal tes pilihan ganda tiga tingkat. Subjek penelitian ini adalah siswa SMA N 3 Padang Panjang kelas X IPS yang sedang atau telah mempelajari materi konsep ciri-ciri sosiologi. Populasi dalam penelitian ini adalah 150 orang, sedangkan yang menjadi sampelnya sebanyak 60 orang. Teknik dalam pengambilan sampel ini menggunakan Stratified Random Sampling (pengambilan sampel acak berstrata). Dalam pengembangan soal ini, model yang dipakai ialah model yang dipaparkan oleh ahli, yakni Tessmer (formative evaluation) yang meliputi beberapa prosedur/ langkah-langkah, antara lain: tahap preliminary, tahap self evauation, tahap prototyping (validasi, evaluasi, dan revisi), dan tahap field test (Mutmainna et al., 2018). Teknik dalam mengumpulkan data dalam penelitian ini menggunakan tes dan angket. Tes yang diberikan berupa soal-soal tes diagnostik sub materi ciri-ciri sosiologi, sedangkan angket berisi sejumlah pernyataan tertulis untuk mengetahui respon siswa (angket efektivitas), dan angket untuk validator berupa angket praktikabilitas). Instrumen penelitian yang digunakan adalah instrumen tes (soal-soal), lembar validasi, serta angket (respon siswa). Teknik analisis data meliputi beberapa analis, mulai dari analisis validitas hingga analisis pemahaman siswa (mengerti konsep, miskonsepsi, dan tidak mengerti konsep).

\section{Hasil dan Pembahasan}

\section{Validitas Isi Tes Diagnostik Pilihan Objektif Tiga Tingkat}

Validator bertugas untuk menilai setiap aspek yang ada pada lembar validasi yang telah disediakan. Lembar validator berisi 3 aspek yang akan dinilai, antara lain aspek konstruksi (perintah), aspek penggunaan bahasa serta aspek alokasi waktu dalam pengerjaan soal tersebut. Validasi isi dianalisis dengan metode CVR dan CVI.

Tabel 4. CVR dan CVI Validasi Isi

\begin{tabular}{c|c|c|c|c|c}
\hline $\begin{array}{c}\text { Butir } \\
\text { soal }\end{array}$ & $\begin{array}{c}\text { Expert } \\
\mathbf{1}\end{array}$ & $\begin{array}{c}\text { Expert } \\
\mathbf{2}\end{array}$ & $\begin{array}{c}\text { Expert } \\
\mathbf{3}\end{array}$ & $\mathbf{C V R}$ & Keterangan \\
1 & 4 & 3 & 4 & 0,91 & Tes sangat mendukung validitas isi \\
2 & 4 & 4 & 4 & 1 & Tes sangat mendukung validitas isi \\
3 & 4 & 4 & 4 & 1 & Tes sangat mendukung validitas isi \\
4 & 4 & 3 & 2 & 0,75 & Tes telah mendukung validitas isi \\
5 & 4 & 4 & 3 & 0,91 & Tes sangat mendukung validitas isi \\
6 & 4 & 4 & 4 & 1 & Tes sangat mendukung validitas isi \\
7 & 3 & 4 & 4 & 0,91 & Tes sangat mendukung validitas isi \\
8 & 4 & 4 & 3 & 0,91 & Tes sangat mendukung validitas isi \\
9 & 4 & 4 & 3 & 0,91 & Tes sangat mendukung validitas isi
\end{tabular}

Jurnal Sikola: Jurnal Kajian Pendidikan dan Pembelajaran Vol. 1, No. 1, Th. 2019 


\begin{tabular}{l|l|l|l|c|c}
10 & 3 & 4 & 3 & 0,83 & $\begin{array}{c}\text { Guna Mendeteksi Miskonsepsi Ciri-Ciri Sosio } \\
\text { Tes telah mendukung validitas isi }\end{array}$ \\
11 & 4 & 4 & 3 & 0,91 & Tes sangat mendukung validitas isi \\
12 & 4 & 4 & 2 & 0,83 & Tes telah mendukung validitas isi \\
13 & 4 & 4 & 2 & 0,83 & Tes telah mendukung validitas isi \\
14 & 4 & 4 & 4 & 1 & Tes sangat mendukung validitas isi \\
15 & 4 & 4 & 3 & 0,91 & Tes sangat mendukung validitas isi \\
16 & 4 & 4 & 2 & 0,83 & Tes telah mendukung validitas isi \\
17 & 4 & 3 & 3 & 0,83 & Tes telah mendukung validitas isi \\
18 & 3 & 3 & 4 & 0,83 & Tes telah mendukung validitas isi \\
19 & 4 & 4 & 4 & 1 & Tes sangat mendukung validitas isi \\
20 & 4 & 4 & 3 & 0,91 & Tes sangat mendukung validitas isi \\
\end{tabular}

Dari tabel 4 di atas, diketahui bahwa semua tes tidak ada yang perlu diperbaiki, karena melihat total rata-rata (CVI) diperoleh sebesar 0,90. Ini menunjukkan bahwa CVI yang dihasilkan memenuhi kriteria dengan interpretasi sangat sesuai.

\section{Analisis Angket respon siswa}

Angket efektifitas atau sering juga disebut angket respon siswa diberikan kepada siswa untuk melihat apakah soal yang diberikan telah dianggap efektif untuk diujikan. Pada ujicoba one-to-one, angket diberikan kepada 3 orang siswa, sedangkan pada ujicoba skala kecil angket diberikan kepada 6 orang siswa. Siswa yang diuji ini dipilih dari kecerdasannya, ada yang tingkat kecerdasannya tinggi, menengah dan rendah.

Setelah angket efektifitas diisi oleh siswa, dari 10 pernyataan terlihat hasil analisis pada tahap ujicoba one-to-one, semua siswa memberikan respon positif pada tiap pernyataan, dengan persentase $100 \%$, begitu juga pada ujicoba skala kecil, siswa juga $100 \%$ memberikan respon positif. Hal ini menandakan bahwa angket respon efektifitas siswa masuk pada kategori "tercapai".

\section{Uji Reliabilitas Tes Diagnostik Pilihan Objektif Tiga Tingkat}

Berdasarkan hasil yang didapatkan pada fild test yang mengikutsertakan siswa kelas X IPS SMA N 3 Padang Panjang, dengan jumlah populasi sebanyak 60 orang siswa. Uji reliabelitas menunjukkan bahwa alpha sebesar 0,457 dengan kategori cukup. Ini berarti bahwa soal tes tersebut cukup bisa dipercaya dalam mendeteksi pemahaman konsep sosiologi.

\section{Uji Tingkat kesukaran Tes Diagnostik Pilihan Objektif Tiga Tingkat}

Soal-soal yang dapat dipakai adalah soal-soal yang memiliki tingkat kesukaran antara 0,30-0,70. Soal yang baik itu tidak terlalu mudah dan tidak juga terlalu sulit. Berdasarkan uji field test diperoleh tingkat kesukaran sebagai berikut:

\section{Tabel 5. Hasil Uji Tingkat Kesukaran Instrumen Tes Diagnostik Pilihan Objektif Tiga} Tingkat

\begin{tabular}{ccccc}
\hline Nomor & Kriteria & Nomor soal & Total & Persentase \\
\hline 1 & Sulit & $1,5,8,9,13,14,17,19$ & 8 & $40 \%$
\end{tabular}

Jurnal Sikola: Jurnal Kajian Pendidikan dan Pembelajaran Vol. 1, No. 1, Th. 2019 


\begin{tabular}{ccccc}
\hline 2 & Sedang & $2,3,4,6,12,15,16,18$ & 8 & $40 \%$ \\
\hline 3 & mudah & $7,10,11,20$ & 4 & $20 \%$ \\
\hline
\end{tabular}

Dari tabel 5 diperoleh gambaran tingkat kesukaran soal yang telah dikembangkan, sebanyak 20 soal yang dikembangkan/ diujikan, 8 diantaranya masuk kriteria sulit, sama dengan kriteria sedang juga berjumlah 8 soal, sedangkan selebihnya masuk pada kriteria mudah yaitu sebanyak 4 soal. Soal pada kriteria sulit memiliki persentase $40 \%$, pada kriteria sedang juga $40 \%$, dan pada kriteria mudah sebanyak $20 \%$.

\section{Daya Beda Tes Diagnostik Pilihan Objektif Tiga Tingkat}

Daya beda yang baik untuk sebuah soal berada pada interval 0,40-0,70. Berikut daya beda yang didapatkan dari uji field tes yang telah dilakukan :

Tabel 6. Daya Beda Tes Diagnostik Pilihan Objektif Tiga Tingkat

\begin{tabular}{ccccc}
\hline No & Kriteria & Butir soal & Total & Persentase \\
\hline 1 & Jelek & $3,5,7,8,9,10,11,14$ & 8 & $40 \%$ \\
\hline 2 & Cukup & $2,4,6,12,13,15,16,18,19,20$ & 10 & $50 \%$ \\
\hline 3 & Baik & 1,17 & 2 & $10 \%$ \\
\hline 4 & Baik sekali & 0 & 0 & $0 \%$ \\
\hline & Jumah total & & 20 & $100 \%$ \\
\hline
\end{tabular}

Tabel 6 memberikan gambaran bahwa daya beda soal yang telah diujikan dari 20 butir soal, terdapat 8 soal (40\%) masuk kriteria jelek, 10 soal (50\%) masuk kriteria cukup, dan kriteria baik sebanyak 2 soal (10\%). Dari hasil ini, dapat dilihat kemampuan siswa dalam menjawab tes diagnostik pilihan objektif itu ternyata berbeda-beda

\section{Tingkat Pemahaman Siswa}

Tes yang diujikan terdiri dari 20 butir soal, dan setiap soal terdiri dari tiga tingkatan. Tingkatan pertama berisi soal, tingkatan kedua berisi alasan menjawab soal, dan tingkat ketiga berisi tingkat keyakinan menjawab soal dan memberikan alasan menjawab soal. Setiap tingkatan diberikan 4 opsi yang akan dipilih, 1 merupakan opsi yang benar, dan 3 opsi lagi sebagai opsi pengecoh. Berikut jumlah jawaban benar siswa dalam menjawab soal tes diagnostik pilihan objektif tiga tingkat dalam mendeteksi miskonsepsi sosiologi:

Tabel 7. Jumlah Jawaban Benar yang Diperoleh Siswa

\begin{tabular}{cccc}
\hline No & Nama responsen & Jumlah benar & $\begin{array}{c}\text { Persentase skor } \\
\text { (\%) }\end{array}$ \\
\hline 1. & A & 5 & 25 \\
\hline 2. & B & 7 & 35 \\
\hline 3. & C & 9 & 45 \\
\hline 4. & D & 5 & 25 \\
\hline 5. & E & 7 & 35 \\
\hline 6. & F & 8 & 40 \\
\hline 7. & G & 7 & 35
\end{tabular}

Jurnal Sikola: Jurnal Kajian Pendidikan dan Pembelajaran Vol. 1, No. 1, Th. 2019

ISSN. 2715-1735 

Guna Mendeteksi Miskonsepsi Ciri-Ciri Sosiologi

\begin{tabular}{|c|c|c|c|}
\hline & & \\
\hline 8. & $\mathrm{H}$ & 14 & 70 \\
\hline 9. & I & 13 & 65 \\
\hline 10. & $\mathrm{~J}$ & 13 & 65 \\
\hline 11. & $\mathrm{~L}$ & 5 & 25 \\
\hline 12. & $\mathrm{M}$ & 10 & 50 \\
\hline 13. & $\mathrm{~N}$ & 10 & 50 \\
\hline 14. & 0 & 10 & 50 \\
\hline 15. & $\mathrm{P}$ & 13 & 65 \\
\hline 16. & $\mathrm{Q}$ & 6 & 30 \\
\hline 17. & $\mathrm{R}$ & 10 & 50 \\
\hline 18. & $\mathrm{~S}$ & 16 & 80 \\
\hline 19. & $\mathrm{~T}$ & 7 & 35 \\
\hline 20. & $\mathrm{H}$ & 5 & 25 \\
\hline 21. & I & 10 & 50 \\
\hline 22. & $\mathrm{~J}$ & 11 & 55 \\
\hline 23. & $\mathrm{~K}$ & 7 & 35 \\
\hline 24. & $\mathrm{~L}$ & 13 & 65 \\
\hline 25. & $\mathrm{M}$ & 8 & 40 \\
\hline 26. & $\mathrm{~N}$ & 10 & 50 \\
\hline 27. & 0 & 16 & 80 \\
\hline 28. & $\mathrm{P}$ & 6 & 30 \\
\hline 29. & $\mathrm{Q}$ & 7 & 35 \\
\hline 30. & $\mathrm{R}$ & 9 & 45 \\
\hline 31. & $S$ & 4 & 20 \\
\hline 32. & $\mathrm{~T}$ & 6 & 30 \\
\hline 33. & $\mathrm{U}$ & 9 & 45 \\
\hline 34. & $\mathrm{~V}$ & 9 & 45 \\
\hline 35. & $\mathrm{~W}$ & 10 & 50 \\
\hline 36. & $X$ & 7 & 35 \\
\hline 37. & $\mathrm{Y}$ & 9 & 45 \\
\hline 38. & $\mathrm{Z}$ & 12 & 60 \\
\hline 39. & $\mathrm{AB}$ & 7 & 35 \\
\hline 40. & $\mathrm{AC}$ & 9 & 45 \\
\hline 41. & $\mathrm{AD}$ & 9 & 45 \\
\hline
\end{tabular}

Jurnal Sikola: Jurnal Kajian Pendidikan dan Pembelajaran Vol. 1, No. 1, Th. 2019

ISSN. 2715-1735 


\begin{tabular}{|c|c|c|c|}
\hline 42. & $\mathrm{AE}$ & 9 & 45 \\
\hline 43. & $\mathrm{AF}$ & 5 & 25 \\
\hline 44. & $\mathrm{AG}$ & 8 & 40 \\
\hline 45. & $\mathrm{AH}$ & 8 & 40 \\
\hline 46. & $\mathrm{AI}$ & 8 & 40 \\
\hline 47. & $\mathrm{AJ}$ & 7 & 35 \\
\hline 48. & $\mathrm{AK}$ & 9 & 45 \\
\hline 49. & $\mathrm{AL}$ & 9 & 45 \\
\hline 50. & $\mathrm{AM}$ & 7 & 35 \\
\hline 51. & AN & 8 & 40 \\
\hline 52. & $\mathrm{AO}$ & 8 & 40 \\
\hline 53. & $\mathrm{AP}$ & 10 & 50 \\
\hline 54. & $\mathrm{AQ}$ & 9 & 45 \\
\hline 55. & $\mathrm{AR}$ & 12 & 60 \\
\hline 56. & AS & 11 & 55 \\
\hline 57. & $\mathrm{AT}$ & 9 & 45 \\
\hline 58. & $\mathrm{AU}$ & 5 & 25 \\
\hline 59. & $\mathrm{AV}$ & 10 & 50 \\
\hline 60. & AW & 14 & 70 \\
\hline
\end{tabular}

Berdasarkan tabel 8 terlihat kemampuan siswa dalam menjawab soal tidaklah sama. Jumlah benar siswa paling rendah adalah benar 4 soal (20\%), sedangkan jumlah benar siswa paling tinggi adalah benar 16 soal (80\%). Hasil ini belum dapat menunjukkan tingkat miskonsepsi yang dialami oleh siswa, karena siswa yang jawaban paling sedikit belum tentu mengalami miskonsepsi atau tidak mengerti konsep, begitu juga sebaliknya siswa yang jawaban benarnya paling tinggi belum bisa dikategorikan mengerti kana konsep, sebelum dilihat alasan dan tingkat keyakinan mereka dalam menjawab soal.

Siswa yang mengerti konsep adalah siswa yang menjawab tingkat 1 benar, tingkat 2 benar, dan tingkat 3 (tingkat keyakinan tinggi/ 3-4), siswa yang mengalami miskonsepsi adalah siswa yang menjawab tingkat 1 benar, tingkat 2 salah, dan tingkat 3 (tingkat keyakinan tinggi/3-4) atau tingkat 1 salah, tingkat 2 benar, dan tingkat 3 (tinggi/3-4), dan siswa yang tidak mengerti konsep adalah siswa yang jawaban tingkat 1 salah, tingkat 2 salah, dan tingkat 3 (rendah/tinggi). Berikut siswa yang mengerti konsep, miskonsepsi, dan tidak mengerti konsep.

Jurnal Sikola: Jurnal Kajian Pendidikan dan Pembelajaran Vol. 1, No. 1, Th. 2019 
Tabel 8. Persentase Mengerti Konsep, Miskonsepsi dan Tidak Mengerti Konsep

\begin{tabular}{|c|c|c|c|c|c|c|}
\hline \multirow{3}{*}{$\begin{array}{l}\text { Nomor } \\
\text { soal }\end{array}$} & \multicolumn{6}{|c|}{ Kriteria } \\
\hline & \multicolumn{2}{|c|}{ Mengerti Konsep } & \multicolumn{2}{|c|}{ Miskonsepsi } & \multicolumn{2}{|c|}{$\begin{array}{l}\text { Tidak Mengerti } \\
\text { Konsep }\end{array}$} \\
\hline & Jumlah & $\begin{array}{c}\text { Persentase } \\
\text { (\%) }\end{array}$ & Jumlah & $\begin{array}{c}\text { Persentase } \\
\text { (\%) }\end{array}$ & Jumlah & $\begin{array}{c}\text { Persentase } \\
\text { (\%) }\end{array}$ \\
\hline 1 & 16 & 27 & 34 & 57 & 10 & 17 \\
\hline 2 & 39 & 65 & 17 & 28 & 4 & 7 \\
\hline 3 & 19 & 32 & 32 & 53 & 9 & 15 \\
\hline 4 & 24 & 40 & 32 & 53 & 4 & 7 \\
\hline 5 & 13 & 22 & 40 & 67 & 7 & 12 \\
\hline 6 & 26 & 43 & 32 & 53 & 2 & 33 \\
\hline 7 & 50 & 83 & 7 & 12 & 3 & 5 \\
\hline 8 & 13 & 22 & 39 & 65 & 8 & 13 \\
\hline 9 & 13 & 22 & 37 & 62 & 10 & 17 \\
\hline 10 & 55 & 92 & 4 & 7 & 1 & 2 \\
\hline 11 & 47 & 78 & 13 & 22 & 0 & 0 \\
\hline 12 & 30 & 50 & 19 & 32 & 11 & 18 \\
\hline 13 & 16 & 27 & 34 & 57 & 10 & 17 \\
\hline 14 & 15 & 25 & 35 & 58 & 10 & 17 \\
\hline 15 & 24 & 40 & 23 & 38 & 13 & 22 \\
\hline 16 & 36 & 60 & 24 & 40 & 0 & 0 \\
\hline 17 & 18 & 30 & 37 & 62 & 5 & 8 \\
\hline 18 & 28 & 47 & 25 & 42 & 7 & 12 \\
\hline 19 & 6 & 10 & 48 & 80 & 6 & 10 \\
\hline 20 & 50 & 83 & 10 & 17 & 0 & 0 \\
\hline jumlah & 538 & 898 & 542 & 905 & 120 & 232 \\
\hline $\begin{array}{l}\text { Rata- } \\
\text { rata }\end{array}$ & 26,9 & 44,9 & 27,1 & 45,25 & 6 & 11,6 \\
\hline
\end{tabular}

Berdasarkan tabel 8, siswa yang masuk kategori mengerti konsep sebesar 44,9 \%, siswa yang berada pada kategori miskonsepsi terdeteksi sebesar 45,25\%, sedangkan siswa yang masuk kategori tidak mengerti akan konsep sebesar 11,6\%.

Variasi desain pembelajaran membuat siswa senang mengikuti pelajaran. Hal itu ditunjukkan oleh antusiasme siswa dalam setiap kegiatan pembelajaran. Deskripsi rata-rata dari berbagai cara penilaian di atas, itu menunjukkan bahwa rata-rata siswa mengalami perubahan dalam hasil belajar. (Sylvia, Anwar, \& Khairani, 2018)

Jurnal Sikola: Jurnal Kajian Pendidikan dan Pembelajaran Vol. 1, No. 1, Th. 2019 


\section{Kesimpulan}

Tes diagnostik pilihan ganda tiga tingkat pada sub materi ciri-ciri sosiologi yang dikembangkan memenuhi kriteria dilihat dari validitas dan reliabilitasnya, indeks validitas isi (CVI) sebesar 1, sedangkan validasi soal dari 20 butir terdapat 8 butir soal dianggap valid dan reliabilitasnya sebesar 0,457 dan ini masuk pada kategori cukup. Miskonsepsi pada siswa telah teridentifikasi. Persentase siswa yang paham konsep terdiri dari 44,9\%, mengalami miskonsepsi sebanyak $45,25 \%$ dan yang masuk pada kategori tidak paham konsep sebanyak $11,6 \%$.

\section{Daftar Pustaka}

Belajar, K., \& Di, M. (n.d.). Pengembangan Tes Diagnostik Kesulitan Belajar Matematika Di Sma Oleh: Irzani. 1-15.

Di, M., \& Serang, S. D. N. (2013). Remedial Untuk Meningkatkan Hasil Belajar. 5(2), 128-134.

Fernandes, R., Putra, E. V., \& Muspita, R. (2013). Optimalisasi Institusi Pendidikan Sebagai Upaya. (April 2019).

Fisika, K., Kelas, S., Sma, X. I., \& Malang, N. (2013). Pengembangan instrumen tes pilihan ganda distraktor bermakna untuk mengidentifikasi karakteristik konsepsi fisika siswa kelas xi sma negeri 2 malang. 1-13.

Ismara, K. I., \& Tanumihardja, E. (2015). Pengembangan sistem tes diagnostik kesulitan belajar kompetensi dasar kejuruan siswa smk. 19(2).

Jurusan, D., \& Penyuluhan, B. (n.d.). Urgensi diagnosis dalam mengatasi kesulitan belajar. 1-14.

Manfaatnya, D. A. N., \& Mengukur, D. (2009). Konsepsi Kimia Siswa SMA. 51-58.

Mutmainna, D., Mania, S., Sriyanti, A., Diagnostik, T., Ganda, P., Tingkat, D., \& Konsep, P. (2018). https://doi.org/10.24252/mapan.2018v6n1a 6 Pengembangan Instrumen Tes Diagnostik Pilihan Ganda Dua Tingkat Untuk Mengidentifikasi Pemahaman Konsep Matematika. 6, 5669.

Nofiana, M., Julianto, T., Nofiana, M., Julianto, T., Adita, A., Purwokerto, U. M., ... Sains, I. K. (2013). Pengembangan Two-Tier Multiple Choice Question Disertai Teknik Cri ( Certainty Of Response Index ) Sebagai Instrumen. 796-802.

Pembimbing, R. D., Universitas, P., Makassar, N., Pembimbing, D., Universitas, P., \& Makassar, N. (n.d.). Ruslan Dosen Pembimbing 1 Pascasarjana Universitas Negeri Makassar 2 Dosen Pembimbing 2 Pascasarjana Universitas Negeri Makassar 3.

Pendidikan, J. I., Malang, U. K., Pratiwi, H. Y., Pendidikan, P., Universitas, F., \& Malang, K. (2016). PENGEMBANGAN INSTRUMEN TES PILIHAN GANDA. 842-850.

Sanjaya, W. (2008). Strategi Pembelajaran Berorientasi Standar Proses Pendidikan. Jakarta: Kencana.

Sdn, D. I., Tujuh, K., \& Kecamatan, D. I. (n.d.). No Title. 10-18.

Soekanto, S. (2017). Sosiologi Suatu Pengantar. Jakarta: PT RajaGrafindo Persada.

Sugiyono. (2017). Metode Penelitian dan Pengembangan (Research and Development/R\&D). Bandung: Alfabeta.

Suwarto. (2013). Pengembangan Tes Diagnostik dalam Pembelajaran. Yogyakarta: Pustaka Pelajar.

Sylvia, I., Anwar, S., \& Khairani, K. (2018). Developing an Authentic Project-Based Assessment Model on Sociology Learning of Senior High School Students. PROCEEDING ICESST 2018 International Conferences on Education ,Social Sciences and Technology, 412-421. https://doi.org/10.29210/2018159

Tes, P., Untuk, D., Miskonsepsi, M., R, D. F., Chandra, E., \& Gloria, R. Y. (2013). [November 2013]. 2(November).

Zulfikar, A., Samsudin, A., \& Saepuzaman, D. (2017). Pengembangan Terbatas Tes Diagnostik Force Concept Inventory Berformat Four-Tier Test. 2(1), 43-49.

Jurnal Sikola: Jurnal Kajian Pendidikan dan Pembelajaran Vol. 1, No. 1, Th. 2019

ISSN. 2715-1735

Copyright@2019, by Author 